\title{
The nutritive value of industrial by-products for poultry
}

\author{
TUOMO KIISKINEN
}

KIISKINEN, T. 1992. The nutritive value of industrial by-products for poultry. Agric. Sci. Finl. 1: 203-210. (Agric. Res. Centre of Finland, Inst. Anim. Prod., SF31600 Jokioinen, Finland.)

The metabolizable energy (ME) and partly also the digestibility of several industrial by-products, mainly originating from grain, were determined in trials with adult cockerels. Five experiments were performed using a conventional total collection procedure, and test ingredients were substituted for $25-40 \%$ of the basal diet.

The nitrogen-corrected apparent $\left(\mathrm{AME}_{\mathrm{n}}\right)$ and true $\left(\mathrm{TME}_{\mathrm{n}}\right)$ metabolizable energy values of distillers' dried grains (DDG) and distillers' dried grains with solubles (DDGS) derived from barley, wheat and rye varied from 7.85 to 11.8 and from 7.98 to 12.0 MJ/ kg DM, respectively. The highest $\mathrm{ME}_{\mathrm{n}}$ values were observed in the dehulled barley-derived products. The digestibility of crude protein (CP) was 62-83 and that of carbohydrates $25-50 \%$, the latter being lowest for feeds originating from whole barley grain. The results indicated that distillers' feeds derived from dehulled grain, especially barley, are satisfactory energy sources for poultry diets.

Dried barley protein (BP 1, CP $38 \%$ ), oats protein (CP $44 \%$ ) and distillers' solids (CP $58 \%$ ) from the integrated ethanol starch process, as well as dehulled barley and oats proved to be excellent energy feeds containing AME $_{\mathrm{n}}$ 14.9, 18.6, 15.0, 14.2 and 14.6 MJ/kg DM, respectively. The TME values for $\mathrm{BP}^{\mathrm{n}}$ and dehulled grains were $15.3,14.4$ and $14.8 \mathrm{MJ} / \mathrm{kg}$ DM. Supplementation with enzymes did not significantly improve the ME value of dehulled barley. The $\mathrm{AME}_{\mathrm{n}}$ values for barley protein (BP2, CP $27 \%$ ), barley bran and barley molasses obtained from the starch process, and wheat feed meal from the milling industry, were $13.3,8.52,13.5$ and $10.6 \mathrm{MJ} / \mathrm{kg} \mathrm{DM}$, respectively. The lowest ME values were obtained for samples of wheat bran, dried potato pulp and malt sprouts: $\mathrm{AME}_{\mathrm{n}} 6.09,6.23$ and 6.01; $\mathrm{TME}_{\mathrm{n}} 6.15,6.07$ and 6.01 $\mathrm{MJ} / \mathrm{kg} \mathrm{DM}$, respectively.

Key words: distillery feeds, barley feed fractions, milling products, metabolizable energy, digestibility, cockerels

\section{Introduction}

Numerous by-products are produced in the processes of the food and alcohol industries. Many of these are potential sources of energy and protein also for poultry diets, and new processing techniques such as the integrated ethanol-starch process (LEHMUS-
SAARI and HAM 1987) are being developed enabling more specific fractionation of raw materials. This report describes trials to determine the nutritive value of products from the Finnish food and alcohol industries using grain as a principal raw material including their ME content and digestibility. 


\section{Material and methods}

\section{Animals and housing}

The birds included in this study were 30-52 weeks old White Leghorn males. They were kept in individual wire cages under housing conditions described earlier by KIISKINEN and HUIDA (1984). Before the start of the experiments the cocks were weighed and devided into groups of six birds in such a way that the average live weights varied as little as possible from one group to another.

\section{Test ingredients}

The distillery products assayed in Experiments 1 and 2 (Table 1) were received from the Finnish alcohol industry (ALKO Ltd). Distillers' dried grains (DDG) and distillers' dried grains with solubles (DDGS) were produced in the conventional distillery process utilizing dehulled barley (BDDG, BDDGS), hulled barley (BDDGH, BDDGSH), wheat (WDDGS) or rye (RDDGS) as raw material. Two components from the alcoholstarch process described by NÄSI (1988), barley protein (BP 1) and barley fibre, were also included in Experiment 1 (Table 2). Later an other sample of BP1 and samples of distillers' solids (a fraction obtained from the distillation of B-starch) and oats protein from the same process were examined (Expt 5). The barley starch process developed by the Raisio Group also produces a barley protein product (BP 2). A sample of BP 2 and samples of barley bran and barley molasses from the same process were studied in Experiment 3 (Table 2). In addition to the above test materials, several products from the milling industry (wheat feed meal, wheat bran, dehulled barley and oats, malt sprouts), as well as dried potato pulp from the potato starch industry (Hämeen Peruna Ltd) were included in the present study (Expts 1 and 4).

\section{Experimental procedures}

Five separate trials were conducted to determine the ME values of the dietary ingredients. A total excreta collection procedure was applied for the difference trials. The test ingredients generally replaced $25-40 \%$ (molasses $10 \%$ ) of the basal diet, which normally consisted of $5 \%$ fish meal, $91 \%$ barley, $1 \%$ rapeseed oil, $1 \%$ dicalcium phosphate, $1 \%$ calcium carbonate, $0,3 \%$ sodium chloride and

Table 1. Proximate analysis and gross energy (GE) content of the distillery feeds.

\begin{tabular}{|c|c|c|c|c|c|c|c|c|}
\hline \multirow{2}{*}{\multicolumn{2}{|c|}{ Test ingredient ${ }^{1)}$}} & \multirow{3}{*}{$\begin{array}{l}\begin{array}{l}\text { Dry } \\
\text { matter } \\
\%\end{array} \\
94.5\end{array}$} & \multicolumn{4}{|c|}{ In dry matter \% } & \multirow[b]{2}{*}{$\mathrm{NFE}^{2}{ }^{2}$} & \multirow{2}{*}{$\begin{array}{l}\text { GE MJ/ } \\
\text { kg DM }\end{array}$} \\
\hline & & & $\begin{array}{l}\text { crude } \\
\text { protein }\end{array}$ & $\begin{array}{l}\text { ether } \\
\text { extract }\end{array}$ & $\begin{array}{l}\text { crude } \\
\text { fibre }\end{array}$ & ash & & \\
\hline BDDG & (Expt 1) & & 37.5 & 11.5 & 10.4 & 4.1 & 36.5 & 22.41 \\
\hline BDDGS & $“$ & 90.0 & 34.8 & 10.8 & 8.0 & 5.5 & 40.9 & 21.98 \\
\hline BDDGH & “ & 92.3 & 29.3 & 10.2 & 16.1 & 3.9 & 40.5 & 21.81 \\
\hline BDDGSH & “ & 91.9 & 31.0 & 9.3 & 15.4 & 4.3 & 40.0 & 21.45 \\
\hline RDDGS & “ & 92.9 & 33.9 & 7.9 & 8.2 & 6.1 & 43.9 & 21.35 \\
\hline WDDGS & $"$ & 92.8 & 41.5 & 8.6 & 9.4 & 3.9 & 36.6 & 22.16 \\
\hline WDDGS 1 & (Expt 2) & 95.9 & 31.8 & 4.3 & 8.2 & 13.6 & 42.1 & 19.29 \\
\hline WDDGS 2 & “ & 95.8 & 35.6 & 2.9 & 7.3 & 13.5 & 40.7 & 19.45 \\
\hline WDDGS 3 & “ & 95.2 & 40.9 & 4.3 & 8.3 & 7.9 & 38.6 & 20.60 \\
\hline
\end{tabular}

1) $\mathrm{BDDG}=$ distillers' dried grains from dehulled barley

BDDGS = distillers' dried grains with solubles from dehulled barley

$\mathrm{H} \quad=$ derived from hulled barley

$\mathrm{R} \quad=$ rye

$\mathrm{W} \quad=$ wheat

2) $\mathrm{NFE} \quad=$ nitrogen-free extract 
Table 2. Proximate analysis and GE values of the products from the integrated ethanol-starch, starch, and milling processes.

\begin{tabular}{|c|c|c|c|c|c|c|c|}
\hline \multirow[b]{2}{*}{ Test ingredient } & \multirow{2}{*}{$\begin{array}{l}\text { Dry } \\
\text { matter } \\
\%\end{array}$} & \multicolumn{4}{|c|}{ In dry matter $\%$} & & \multirow{2}{*}{$\begin{array}{r}\mathrm{GE} \mathrm{MJ} \\
\mathrm{kg} \mathrm{DM}\end{array}$} \\
\hline & & $\begin{array}{l}\text { crude } \\
\text { protein }\end{array}$ & $\begin{array}{l}\text { ether } \\
\text { extract }\end{array}$ & $\begin{array}{l}\text { crude } \\
\text { fibre }\end{array}$ & ash & $\mathrm{NFE}$ & \\
\hline \multicolumn{8}{|l|}{ Ethanol starch process } \\
\hline Barley protein (BP1 Expt 1) & 96.8 & 37.7 & 6.2 & 0.9 & 3.6 & 51.6 & 20.88 \\
\hline Barley fibre & 96.0 & 14.5 & 8.6 & 13.5 & 1.5 & 61.9 & 20.49 \\
\hline Barley protein (BP1 Expt 5) & 91.2 & 37.9 & 5.4 & 1.7 & 3.0 & 52.0 & 20.87 \\
\hline Oats protein & 88.5 & 44.1 & 14.2 & 0.5 & 3.2 & 38.0 & 22.81 \\
\hline Distillers' solids ( “ ) & 92.5 & 58.2 & 6.1 & 1.9 & 4.2 & 29.6 & 22.69 \\
\hline \multicolumn{8}{|l|}{ Starch production } \\
\hline Barley protein (BP2 Expt 3) & 91.9 & 27.0 & 3.2 & 3.6 & 3.5 & 62.7 & 20.05 \\
\hline Barley bran & 86.7 & 11.8 & 2.7 & 16.7 & 4.6 & 64.2 & 18.87 \\
\hline Barley molasses (" ) & 67.8 & 6.7 & - & - & 3.4 & 89.9 & 17.84 \\
\hline Dried potato pulp ( “ ) & 91.8 & 3.5 & 0.2 & 15.1 & 12.1 & 69.1 & 14.57 \\
\hline \multicolumn{8}{|l|}{ Milling industry } \\
\hline Malt sprouts & 93.6 & 31.1 & 3.7 & 13.8 & 7.4 & 44.0 & 19.01 \\
\hline Wheat feed meal ( " ) & 87.3 & 19.3 & 7.1 & 7.4 & 4.7 & 61.5 & 19.61 \\
\hline Wheat bran & 85.8 & 14.4 & 6.7 & 14.1 & 7.4 & 57.4 & 19.08 \\
\hline Dehulled barley (Expt 1) & 87.7 & 11.6 & 3.5 & 3.4 & 2.3 & 79.2 & 18.50 \\
\hline Dehulled oats & 88.2 & 14.0 & 7.5 & 4.6 & 2.6 & 71.3 & 19.45 \\
\hline
\end{tabular}

$0,7 \%$ vitamin-trace mineral premixes. The diets were pressed into $4 \mathrm{~mm}$ pellets with a laboratory pelleting machine (Amandus Kahl Laborpresse L 175 ) and the daily ration per bird varied from 80 to $110 \mathrm{~g}$ in the experiments. The adaptation and collection periods lasted 4-5 days each. Samples from the basal diets were taken before and after pelleting, and from the test diets after pelleting and two days' drying in room temperature. The excreta were collected from the plates once per day and placed into plastic cans to be kept in a freezer $\left(-20^{\circ} \mathrm{C}\right)$ to await analysis. In order to calculate the true ME values (TME, TME , Expts 1 and 4) excreta of six birds were totally collected during the last 48 hours of the 72 hours' fasting period in order to determine the endogenous energy loss $\left(\mathrm{EEL}, \mathrm{EEL}_{\mathrm{n}}\right.$ ).

\section{Chemical analyses and calculation}

A proximate analysis was performed on each test ingredient, basal diet, test diet and dried excreta samples, according to the standard methods used at the Institute of Animal Production of the Agricultural Research Centre. When digestibilities were determined (Expts 1, 2 and 4) the samples were hydrolyzed with $3 \mathrm{~N} \mathrm{HCl}$ before ether extraction. The thawed excreta samples were weighed mixed and homogenized individually and subjected to an analysis of moisture, total nitrogen (Kjeldahl procedure), urinary nitrogen (TERPSTRA and HART 1974) and $3 \mathrm{~N} \mathrm{HCl}$ ether extract (Expts 1, 2 and 4) before drying in an air oven at $60^{\circ} \mathrm{C}$ for 16 hours. The gross energy (GE) of the feeds and dried excreta samples was measured with an IKA adiabatic bomb calorimeter. The apparent ME values (AME) of the diets were calculated by subtracting the excreta energy from the GE intake and then dividing by total dry matter intake. The values for the feedstuffs were calculated from the differences in the values between the basal diet and the test diet by extrapolation to $100 \%$ feedstuff. The TME values of test diets were calculated by subtracting the EEL of the collection period from the total excreta energy of that period. All ME values were corrected for a nitrogen retention of zero using the 
factor $34.4 \mathrm{~kJ}$ per $\mathrm{g}$ of nitrogen retained or lost (Hill and ANDERSSON 1958). The amount of urine organic matter was calculated by multiplying the amount of uric acid $\mathrm{N}$ by the factor 4 (HARTFIELD 1973). The ME and digestibility data from Experiments 1, 2 and 5 were analyzed by the one-way analysis of variance, and the mean values of the test ingredients were compared using SCHEFFE's multiple range test.

\section{Results and discussion}

The crude protein (CP) content of the distillery feeds derived from barley varied from 29.3 to 37.5 $\%$ and the crude fibre (CF) content from 8.0 to 16.1 $\%$ (Table 1). The highest $\mathrm{CP}$ values and the lowest $\mathrm{CF}$ values were for products obtained from dehulled barley. The $\mathrm{AME}_{\mathrm{n}}$ value of the feeds from dehulled barley was 11.6-11.8 and that of whole barley grain was 7.85-8.36 MJ/kg DM ( $\mathrm{P}<0.05$, Table 3$)$. The starved birds produced excreta 2.7 (Expt 1) and $3.6 \mathrm{~g} \mathrm{DM} / \mathrm{bird} / 24 \mathrm{~h}$ (Expt 4). Endogenous energy losses (EEL and $\mathrm{EEL}_{\mathrm{n}}$ ) were 33 and 12 (Expt 1) and 42 and $9 \mathrm{~kJ} / \mathrm{bird} / 24 \mathrm{~h}$ (Expt 4). The TME $\mathrm{n}_{\mathrm{n}}$ contents for the products from dehulled barley were 11.8 -
12.0 and for those from hulled barley 8.08-8.59 $\mathrm{MJ} / \mathrm{kg}$ DM. (Table 3). The low energy values of the distillery products from whole barley grain are mainly due to their high fibre content and the resulting low digestibility of carbohydrates, $25-27 \%$ in the present study (Table 5). The results obtained with BDDGS and BDDGSH are relatively well in agreement with those reported by ASKBRANT and THOMKE (1986). The corresponding digestibility values for the products derived from dehulled barley were significantly $(\mathrm{P}<0.05)$ higher: 38 (BDDG) and $50 \%$ (BDDGS). The difference $(\mathrm{P}<0.05)$ between BDDG and BDDGS can be considered logical because DDGS contains more available carbohydrates than DDG and the digestibility trials with pigs have also given similar results (NÄSI 1985). The CP digestibilities of BDDGH and BDDGSH were lower than those of BDDG and BDDGS and the values of DDG were higher than those of DDGS. This last result is in agreement with the results obtained with pigs (NÄSI 1985). In the European table for poultry feedstuffs (WPSA 1989) the $\mathrm{AME}_{\mathrm{n}}$ value for BDDGSH is 11.05 $\mathrm{MJ} / \mathrm{kg} \mathrm{DM}$, which is remarkably higher than that obtained in the present study. The CF value for

Table 3. Total feed intake of the birds $(\mathrm{g} \mathrm{DM})$ and $\mathrm{ME}$ values $(\mathrm{MJ} / \mathrm{kg} \mathrm{DM})$ of the distillery feeds $(\mathrm{SD}=\mathrm{standard}$ deviation).

\begin{tabular}{|c|c|c|c|c|c|c|c|c|c|c|c|}
\hline $\begin{array}{l}\text { Test }^{1)} \\
\text { ingredient }\end{array}$ & $\begin{array}{l}\text { Feed } \\
\text { intake } \\
\text { Mean }\end{array}$ & SD & $\mathrm{AME}^{2)}$ & SD & $\mathrm{AME}_{\mathrm{n}}{ }^{2)}$ & SD & $\mathrm{TME}^{2)}$ & SD & $\mathrm{TME}_{\mathrm{n}}{ }^{2)}$ & SD & $\begin{array}{l}\operatorname{AME}_{n} \% \\
\text { from GE }\end{array}$ \\
\hline$\overline{\mathrm{BDDG}}$ & 316 & 40.6 & $11.55^{\mathrm{cd}}$ & 0.23 & $11.59^{\mathrm{cd}}$ & 0.46 & $12.12^{\text {cd }}$ & 0.38 & $11.75^{\mathrm{cd}}$ & 0.66 & 51 \\
\hline BDDGS & 341 & 3.5 & $11.87^{\mathrm{d}}$ & 0.64 & $11.79^{d}$ & 0.62 & $12.25^{\mathrm{d}}$ & 0.69 & $11.98^{d}$ & 0.65 & 54 \\
\hline BDDGH & 337 & 16.8 & $8.41^{\mathrm{a}}$ & 0.21 & $8.36^{a}$ & 0.30 & $8.88^{a}$ & 0.25 & $8.59^{a}$ & 0.34 & 38 \\
\hline BDDGSH & 331 & 22.9 & $7.88^{\mathrm{a}}$ & 1.37 & $7.85^{\mathrm{a}}$ & 1.06 & $8.34^{a}$ & 0.93 & $8.08^{a}$ & 0.62 & 37 \\
\hline RDDGS & 319 & 38.2 & $10.07^{\mathrm{b}}$ & 0.61 & $10.19^{b}$ & 0.79 & $10.56^{b}$ & 0.62 & $10.08^{b}$ & 0.91 & 48 \\
\hline WDDGS & 336 & 7.1 & $10.47^{\mathrm{bc}}$ & 0.61 & $10.54^{b c}$ & 0.60 & $10.91^{b c}$ & 0.57 & $10.59^{\mathrm{bc}}$ & 0.61 & 48 \\
\hline WDDGS1 & 437 & 4.2 & $7.60^{\mathrm{A}}$ & 1.03 & $7.99^{A}$ & 0.81 & - & & - & & 41 \\
\hline WDDGS2 & 443 & 1.9 & $8.96^{\mathrm{AB}}$ & 1.28 & $9.17^{\mathrm{A}}$ & 1.15 & - & & - & & 47 \\
\hline WDDGS3 & 439 & 2.4 & $10.43^{\mathrm{B}}$ & 0.71 & $10.73^{B}$ & 0.70 & - & & - & & 52 \\
\hline
\end{tabular}

\footnotetext{
1) See the explanations of the abbreviations below Table 1 .
}

2) $\mathrm{AME}=$ apparent metabolizable energy, $\mathrm{AME}_{\mathrm{n}}=$ nitrogen corrected $\mathrm{AME}$

$\mathrm{TME}=$ true metabolizable energy, $\mathrm{TME}_{\mathrm{n}}=$ nitrogen corrected $\mathrm{TME}$

$\left.\begin{array}{l}\text { a }-\mathrm{d} \\ \mathrm{A}-\mathrm{B}\end{array}\right\}$ Means in the same column with a different superscript letter are significantly $(\mathrm{P}<0.05)$ different. 
BDDGSH in the above-mentioned table is, however, lower than that of the examined sample.

In the WDDGS samples, CP varied from 31.8 to 41.5 and CF from 7.3 to $9.4 \%$ in dry matter (Table 1). The corresponding values for the RDDGS sample were 33.9 and $8.2 \%$. The $\mathrm{AME}_{\mathrm{n}}$ value for the WDDGS samples which contained around 41 $\%$ CP was 10.5-10.7 MJ/kg DM (Table 3). The samples which contained less protein also had lower ME values $(\mathrm{P}<0.05)$. The $\mathrm{AME}_{\mathrm{n}}$ value of RDDGS was $10.2 \mathrm{MJ} / \mathrm{kg}$ DM. According to these results, distillery feeds from dehulled grains seem to be satisfactory energy sources for poultry. The ME value of products derived from barley was nearly as high as that of their raw material. NÄSI (1990) used the same batches of BDDGS and WDDGS at a rate of up to $20 \%$ in layers' diets without any significant effect on egg production. Dis- tillery feeds supplemented with methione replaced barley and soybean meal in the diets.

Barley protein (BP 1) produced in the ethanolstarch process contains more protein $(38 \%)$ than that (BP 2) obtained in starch production (27\%, Table 2). Both products are relatively rich in metabolizable energy, BP 1 containing $\mathrm{AME}_{\mathrm{n}} 14.9$ and BP $213.3 \mathrm{MJ} / \mathrm{kg}$ DM (Table 4). The values for the two BP 1 samples were very similar. The ME of barley proteins exceeds the table values of barley and in the case of BP $1 \mathrm{ME}$ is similar to the value of wheat (SALO et al. 1990). The high ME value of BP 1 seems to be a result of its excellent digestibility which was $86 \%$ for crude protein, $84 \%$ for crude fat and $80 \%$ for carbohydrates (Table 5). These results are in agreement with the results reported on pigs (NÄSI 1989). The relatively high digestibility of carbohydrates is due to the low fibre content of

Table 4. Total feed intake of the birds ( $\mathrm{g} \mathrm{DM})$ and ME-values $(\mathrm{MJ} / \mathrm{kg} \mathrm{DM})$ of the products from the ethanol-starch, starch and milling processes $(\mathrm{SD}=$ standard deviation).

\begin{tabular}{|c|c|c|c|c|c|c|c|c|c|c|c|}
\hline & $\begin{array}{l}\text { Feed } \\
\text { intake }\end{array}$ & & AME $^{1)}$ & & $\mathrm{AME}_{\mathrm{n}}{ }^{1)}$ & & TME $^{1)}$ & & $\mathrm{TME}_{\mathrm{n}}{ }^{1)}$ & & $\begin{array}{l}\mathrm{AME}_{\mathrm{n}} \\
\% \text { from }\end{array}$ \\
\hline Test ingredient & Mean & SD & Mean & SD & Mean & SD & Mean & SD & Mean & SD & GE \\
\hline Barley protein (BP1) & 333 & 28.6 & 15.04 & 0.40 & 14.83 & 0.48 & 15.52 & 0.48 & 15.27 & 0.51 & 71 \\
\hline Barley fibre & 338 & 23.3 & 9.07 & 0.34 & 9.06 & 0.33 & 9.55 & 0.40 & 9.23 & 0.42 & 44 \\
\hline Barley protein (BP1) & 345 & 9.8 & $15.23^{\mathrm{A}}$ & 0.40 & $14.98^{\mathrm{A}}$ & 0.47 & - & & - & & 72 \\
\hline Oats protein & 331 & 13.9 & $18.88^{\mathrm{B}}$ & 0.64 & $18.59^{\mathrm{B}}$ & 0.64 & - & & - & & 82 \\
\hline Distilled solids & 344 & 10.9 & $15.28^{A}$ & 0.64 & $15.04^{\mathrm{A}}$ & 0.55 & - & & - & & 66 \\
\hline Barley protein (BP2) & 355 & 20.2 & 13.49 & 0.74 & 13.31 & 0.75 & - & & - & & 66 \\
\hline Barley bran & 348 & 7.7 & 8.67 & 0.57 & 8.52 & 0.61 & - & & - & & 45 \\
\hline Barley molasses & 361 & 25.2 & 14.23 & 2.26 & 13.51 & 2.58 & - & & - & & 76 \\
\hline Potato pulp (dried) & 391 & 1.7 & 6.14 & 0.71 & 6.23 & 0.71 & 6.30 & 0.79 & 6.07 & 0.80 & 43 \\
\hline Malt sprouts & 396 & 1.0 & 6.04 & 0.90 & 6.01 & 0.84 & 6.53 & 1.03 & 6.01 & 1.07 & 32 \\
\hline Wheat feed meal & 384 & 0.7 & 10.85 & 0.32 & 10.63 & 0.16 & 11.21 & 0.36 & 10.81 & 0.32 & 54 \\
\hline Wheat bran & 383 & 1.2 & 6.23 & 0.21 & 6.09 & 0.22 & 6.61 & 0.27 & 6.15 & 0.37 & 32 \\
\hline Dehulled barley & 327 & 12.9 & 14.22 & 0.37 & 14.15 & 0.39 & 14.69 & 0.41 & 14.39 & 0.42 & 77 \\
\hline Dehulled barley $+\mathrm{E}^{2)}$ & 330 & 13.5 & 14.57 & 0.41 & 14.52 & 0.36 & 15.07 & 0.45 & 14.63 & 0.41 & 79 \\
\hline Dehulled oats & 309 & 29.2 & 14.61 & 0.69 & 14.60 & 0.66 & 15.24 & 0.79 & 14.84 & 0.76 & 75 \\
\hline
\end{tabular}

1) See the explanations of the abbreviations below Table 3 .

2) an enzyme mixture (ALKO Ltd)

A - B see the foot note below Table 3. 
BP 1. According to NÄsı (1988), BP 1 contains around $40 \%$ of available carbohydrates (starch, sugars). It is relatively poor in methionine 1.8 and lysine 3.2 g/16 N (NÄSI 1989). However, supplemented with the above-mentioned amino acids, BP 1 can be used at a rate of $5-10 \%$ in the broiler finisher diets (KIISKINEN 1988) and up to $20 \%$ in layers' diets, replacing two thirds of soybean meal in the latter case (NÄSI 1990). Oats protein (CP $44 \%$ ) which is obtained from the same process as BP 1 using oats as a raw material, has a very high energy value of $18.6 \mathrm{MJ} / \mathrm{kg}$. The $\mathrm{AME}_{\mathrm{n}}$ of distillers' solids (CP $58 \%$ ) was approximately the same as that of BP 1.

The proximate analysis shows same kind of composition for barley fibre and bran (Table 2). The $\mathrm{AME}_{\mathrm{n}}$ value of barley fibre, $9.06 \mathrm{MJ} / \mathrm{kg} \mathrm{DM}$ was higher than that of barley bran (8.52) from the starch process or that of wheat bran (6.09) from the milling process (Table 4). According to NÄSI (1988) barley fibre contains $18 \%$ available carbohydrates. In the present study the digestibility of total carbohydrates was found to be $48 \%$ and that of wheat bran only $25 \%$ (Table 5). Barley fibre and obviously also barley bran are potential feed ingredients for layers' diets. Barley fibre has successfully been used at a rate of $20 \%$ in layer's diets, replacing barley and soybean meal (NÄSI 1990). The $\mathrm{AME}_{\mathrm{n}}$ of wheat bran was clearly lower than the table values of 7.3-7.8 MJ/kg DM (WPSA 1989, SALO et al. 1990). For wheat feed meal, approximately the same ME value was obtained as given in the feedstuffs tables.

Dehulled grains proved to be rich in metabolizable energy, with barley containing $\mathrm{AME}_{\mathrm{n}} 14.2$ and $\mathrm{TME}_{\mathrm{n}} 14.4 \mathrm{MJ} / \mathrm{kg}$ DM (Table 4). The corresponding values for oats were 14.6 and $14.8 \mathrm{MJ} / \mathrm{kg}$ DM. Supplementation with enzymes did not signi-

Table 5. Apparent digestibility of the products in Experiments 1, 2 and 4 (SD $=$ standard deviation).

\begin{tabular}{|c|c|c|c|c|c|c|}
\hline \multirow[b]{3}{*}{ Test ingredient ${ }^{1)}$} & \multicolumn{6}{|c|}{ Digestibility $\%$} \\
\hline & \multicolumn{2}{|c|}{ Crude protein } & \multicolumn{2}{|c|}{ Crude fat } & \multicolumn{2}{|c|}{ Carbohydrates } \\
\hline & Mean & SD & Mean & SD & Mean & SD \\
\hline BDDG & $82^{c}$ & 4.5 & $81^{a}$ & 1.3 & $38^{\mathrm{b}}$ & 5.0 \\
\hline BDDGS & $66^{\mathrm{ab}}$ & 7.6 & $86^{\mathrm{b}}$ & 3.4 & $50^{c}$ & 3.4 \\
\hline BDDGH & $72^{b}$ & 7.2 & $82^{\mathrm{a}}$ & 2.6 & $25^{\mathrm{a}}$ & 3.8 \\
\hline BDDGSH & $62^{a}$ & 5.2 & $82^{a}$ & 3.6 & $27^{a}$ & 6.4 \\
\hline RDDGS & $72^{b}$ & 8.6 & $84^{\mathrm{ab}}$ & 1.7 & $47^{c}$ & 4.9 \\
\hline WDDGS & $71^{b}$ & 5.1 & $84^{\text {ab }}$ & 1.1 & $40^{b}$ & 2.3 \\
\hline WDDGS 1 & $67^{\wedge}$ & 4.8 & 71 & 4.0 & 31 & 6.7 \\
\hline WDDGS 2 & $75^{\mathrm{B}}$ & 2.1 & 75 & 4.2 & 33 & 10.7 \\
\hline WDDGS 3 & $83^{\mathrm{c}}$ & 4.4 & 73 & 4.3 & 32 & 3.5 \\
\hline Barley protein (BP1) & 86 & 4.5 & 84 & 1.7 & 80 & 3.7 \\
\hline Barley fibre & 54 & 8.5 & 55 & 2.7 & 48 & 2.9 \\
\hline Dehulled barley & 49 & 9.7 & 73 & 3.5 & 81 & 2.0 \\
\hline$" \quad \cdots+E$ & 58 & 15.5 & 61 & 4.8 & 83 & 1.4 \\
\hline Dehulled oats & 71 & 14.2 & 80 & 4.6 & 79 & 2.3 \\
\hline Malt sprouts & 52 & 7.2 & 40 & 17.0 & 27 & 5.0 \\
\hline Wheat feed meal & 70 & 5.9 & 81 & 2.5 & 51 & 1.2 \\
\hline Wheat bran & 58 & 12.7 & 54 & 6.0 & 25 & 1.8 \\
\hline Potato pulp (dried) & - & - & - & - & 46 & 4.9 \\
\hline
\end{tabular}

1) See the explanations of the abbreviations below Table 1 and 4 .

a-c See the footnote below Table 3 
ficantly improve the ME values or the digestibility (Table 5) of dehulled barley. The ME value for dehulled oats was even better than that for wheat (SALO et al. 1990), and dehulled oats have been used as the sole grain in broiler diets (KIISKINEN 1986).

Compared with cane and beet molasses, the ash content of barley molasses from the starch process is only approximately one third (Table 2). This naturally improves the energy value of barley molasses. Its $\mathrm{AME}_{\mathrm{n}}$ value was $13.5 \mathrm{MJ} / \mathrm{kg} \mathrm{DM}$ (Table 4), which is considerably higher than the 10.9-11.05 MJ/kg DM for cane and beet molasses in the European tables (WPSA 1989). Wet droppings were not found in Experiment 3 although the content of molasses was $10 \%$ in the diet. Barley molasses can be considered a good energy source for poultry, comparable with grains of the highest quality.

As energy feeds, dried potato pulp and malt sprouts rank in the same class with wheat bran (Table 2). The $\mathrm{AME}_{\mathrm{n}}$ of potato pulp was 6.23 $\mathrm{MJ} / \mathrm{kg}$ DM. The digestibility of potato pulp carbohydrates was as high as $46 \%$, apparently due to starch left after the process (Table 5). The concentrations of crude protein and crude fat were so low that their digestibility could not be determined with this method. Malt sprouts are rich in protein but the digestibility of this feedstuff was found to be very low and the $\mathrm{AME}_{\mathrm{n}}$ clearly lower than the table value $8.5 \mathrm{MJ} / \mathrm{kg}$ DM for poultry (SALO et al. 1990).

\section{References}

ASKBrant, S \& ThOMKE, S. 1986. The nutritive value distillers grains with solubles from barley and wheat determined with laying hens. J. Anim. Physiol. Anim. Nutr. 56: 185-191.

HaRTFIEld, W. 1973. Richtlinien zur Durchführung von Bilanzversuchen mit Hühnern Arch. Getflügelk. 37: 4957.

Hill, F. W. \& ANDERSON, D. L. 1958. Comparison of metabolizable energy and productive energy determinations with growing chicks. J. Nutr. 64: 587-603.

KIISKINEN, T. 1986. Nutritive value of dehulled oats in broiler diets. 7th Eur. Poultry Conf. Paris. France. Aout Vol 1: 468-471.

- 1988. Barley protein concentrate in broiler diets. XVIII World's Poultry Congr. Nagoya, Japan. Proc.:912-914.

— \& HuIDA, L. 1984. Metabolizable energy values and digestibility of some protein sources for poultry. Ann. Agric. Fenn. 23: 26-38.

LehmussaARI, A. \& Ham van der, W. 1987. New process for the integrated production of barley starch and ethanol. 38 Stärke Tagung. Detmold, FDG. Mimeogr. 14 p.

NĀsı, M. 1985. Distillers feeds from various grains as protein sources for pigs. J. Agric. Sci. Finl. 57: 255-262.

- 1988. Evaluating barley feed fractions from integrated ethanol-starch production in diets of ruminants. J. Agric.
Sci. Finl. 60: 701-709.

- 1989. Barley feed fractions from integrated ethanolstarch process in diets of pigs. J. Agric. Sci. Finl. 61: 441-450.

- 1990. Distillers feeds and feed fractions of barley in the diets of laying hens. J. Agric. Sci. Finl. 62: 423-433.

SAlo, M.-L., TuORI, M. \& KIISKINEN, T. 1990. Rehutaulukot ja ruokintanormit. 70p. 3. uudistettu painos. Yliopistopaino. Helsinki.

TERPSTRA, K. \& HART de, N. 1974. The estimation of urinary nitrogen and faecal nitrogen in poultry excreta. Z. Tierphysiol. Tierernähr. u. Futtermittelk. 32: 306-320.

WPSA 1989. European Table of Energy Values for Poultry Feedstuffs. Subcommittee energy of the Working Group $\mathrm{nr} 2$ Nutrition of the European Federation of Branches of the WPSA. 104 p. 3rd Edition. Grafish bedrijf, Ponsen \& Looijen, Wageningen.

\section{Manuscript received January 1992}

Tuomo Kiiskinen

Agricultural Research Centre of Finland

Institute of Animal Production

SF-31600 Jokioinen, Finland 


\title{
SELOSTUS
}

\section{Eräiden teollisuuden sivutuotteiden ravintoarvo siipikarjalle}

\author{
TUOMO KIISKINEN \\ Maatalouden tutkimuskeskus
}

Păäasiassa viljaperäisten tuotteiden muuntokelpoisen energian (ME) pitoisuutta ja sulavuutta tutkittiin täyskasvuisilla kukoilla tehdyillä määrityksillä. Menetelmänä oli tavallinen ulosteiden kokonaiskeräilyyn perustuva erotusmenetelmä.

Rankkijauhojen, joissa oli raakavalkuaista (rv) 29-41 ja raakakuitua (rk) 7.3-16 \% kuiva-aineesta, typpikorjattu näennäinen $\left(\mathrm{AME}_{\mathrm{n}}\right)$ ja todellinen $\left(\mathrm{TME}_{\mathrm{n}}\right) \mathrm{ME}$-arvo olivat vastaavasti $7.85-11.8$ ja $8.08-12.0 \mathrm{MJ} / \mathrm{kg}$ ka. Korkeimmat arvot todettiin kuoritusta ohrasta saaduissa rankkijauhoissa. Valkuaisen sulavuus vaihteli välillä $62-83$ ja hiilihydraattien $25-50 \%$. Matalimmat hiilihydraattien sulavuusarvot olivat kokonaisesta ohranjyvästä peräisin olevissa rankkijauhoissa. Tulosten perusteella varsinkin kuoritusta ohrasta saatuja rankkijauhoja voidaan pitää tyydyttävinä energian lähteinä siipikarjan rehuihin. Yhdistetystä etanoli-tärkelysprosessista saadut viljanvalkuaistuotteet ohravalkuainen (rv $38 \%$ ), kauravalkuainen (rv $44 \%$ ) ja rankkivalkuainen (rv $58 \%$ ), samoin kuin kuorittu ohra ja kaura sisälsivät runsaasti ME:a, AME $_{\mathrm{n}} 14.9,18.6,15.0,14.2 \mathrm{ja} 14.6 \mathrm{MJ} / \mathrm{kg}$ ka vastaavasti. Entsyymilisäys ei parantanut merkitsevästi kuoritun ohran ME-arvoa. Tärkkelysprosessin sivutuotteiden ohravalkuaisen (rv $27 \%$ ), ohraleseen ja ohramelassin sekä myllyteollisuuden sivutuotteen vehnärehujauhon $\mathrm{AME}_{\mathrm{n}}$-arvot olivat vastaavasti $13.3,8.52,13.5$ ja $10.6 \mathrm{MJ} / \mathrm{kg} \mathrm{ka}$. Alhaisimmat $\mathrm{AME}_{\mathrm{n}}$-arvot todettiin vehnänleseissä (6.09), kuivatussa perunapulpassa $(6.23)$ ja mallasiduissa (6.01). 